\title{
Ram lambs need FSH for normal testicular growth, Sertoli cell numbers and onset of spermatogenesis
}

\author{
Robert J. Kilgour*, Claudine Pisselet, Maurice P. Dubois**, \\ Michel Courot
}

Physiologie de la reproduction, Inra, 37380 Nouzilly, France

(Received 23 July 1997, accepted 5 October 1998)

\begin{abstract}
The effect of FSH on the development of the testis in the ram lamb was examined in two experiments where lambs were passively immunized against ovine $\beta$-FSH from birth until 100 or $160 \mathrm{~d}$. In both experiments, immunization resulted in a slower testicular growth relative to that of controls. This effect became apparent at around the start of the period of rapid testicular growth $(60-70 \mathrm{~d}$ of age) and resulted in testicular weights at the end of treatment ranging from 37 to $51 \%$ of those of control groups. Within the testis, this was reflected in shorter seminiferous tubules (48-64\% of controls) and in lower numbers of Sertoli cells per testis (57-82\%). In the rams immunized until $160 \mathrm{~d}$ of age, spermatogenesis had begun and immunization against FSH provoked a lower production of germinal cells which was not solely due to the lower number of Sertoli cells but also due to fewer germinal cells being supported by each Sertoli cell. However, the numbers of $A_{0}$ spermatogonia per testis and the daily production of the $A_{1}$ spermatogonia were unaffected by immunization, but the production of the $\mathrm{B}_{2}$ spermatogonia and, as a consequence, of leptotene and pachytene spermatocytes and of round spermatids were all markedly lower ( $43-47 \%$ of controls). These effects were not due to any decreases in the secretion of LH or testosterone as seen in the blood levels of these two hormones. These results show that, in the ram lamb, FSH is essential for normal testicular development and for the establishment of a normal population of Sertoli cells. They also confirm that, once spermatogenesis is established, FSH is necessary for a normal production of germinal cells, with one or $\mathrm{m}^{*}$ ore of the divisions between the $A_{1}$ and $B_{2}$ spermatogonia being sensitive to suppression of FSH. (C) Inra/ Elsevier, Paris.
\end{abstract}

FSH / testis / spermatogenesis / Sertoli cells / ram lamb

Résumé - FSH est nécessaire pour le développement normal des testicules, la mise en place de la population des cellules de Sertoli et l'établissement de la spermatogenèse chez l'agneau. L'effet de FSH sur le développement des testicules de l'agneau a été étudié par l'immunisation pas-

\footnotetext{
* Correspondence and reprints: NSW Agriculture, Agricultural Research Centre, Trangie, NSW 2823, Australia

** Deceased
} 
sive d'agneaux mâles contre $\beta$-FSH ovine de leur naissance jusqu'à l'âge de 100 ou 160 j. L'immunisation a provoqué une croissance testiculaire plus faible que celle observée chez les témoins. Cet effet apparaît à partir du début de la période de croissance rapide des testicules $(60$ à 70 j) et aboutit, en fin d'expérience, à un poids testiculaire significativement inférieur à celui des témoins (37 à $51 \%$ ). Ceci résulte de tubes séminiferes plus courts ( 48 à $64 \%$ des témoins) et d'un moindre nombre de cellules de Sertoli par testicule (57 à $82 \%$ ). Chez les animaux immunisés jusqu'à $160 \mathrm{j}$, la spermatogenèse s'est tout de même établie mais avec une plus faible production de cellules germinales due à un plus petit nombre de cellules de Sertoli et à un plus faible nombre de cellules germinales soutenues par chaque cellule de Sertoli. Toutefois, le nombre de spermatogonies $\mathrm{A}_{0}$ par testicule et la production quotidienne de spermatogonies $A_{1}$ ne sont pas affectés par l'immunisation contre FSH. Par contre, la production quotidienne des spermatogonies $B_{2}$ et, par conséquence, celle des spermatocytes leptotène et pachytène et celles des spermatides rondes sont toutes significativement plus faibles que chez les témoins (43 à $47 \%$ ). Ces effets ne sont pas dus à des modifications des sécrétions de LH ou de testostérone qui ne sont pas diminuées. Ces résultats montrent que, chez l'agneau, FSH est indispensable au développement normal des testicules ainsi qu'à l'établissement d'une population suffisante de cellules de Sertoli. Ils confirment aussi que, lorsque la spermatogenèse est établie, FSH est nécessaire pour assurer une production quantitative normale de cellules germinales puisque son immunosuppression affecte fortement une ou plusieurs générations de spermatogonies situées entre les spermatogonies $A_{1}$ et $B_{2}$. O Inra/Elsevier, Paris.

\section{FSH / testicule / spermatogenèse / cellules de Sertoli / agneau}

\section{INTRODUCTION}

In the most detailed studies on the hormonal control of spermatogenesis in the developing ram, Courot $[10,12]$ showed that hypophysectomy of ram lambs soon after birth resulted in a decrease in testicular weight compared to intact initial controls. This was reflected in a decrease in the number of supporting cells and an arrest in the differentiation of the germinal cells. Treatment with FSH and LH partially overcame these effects; when the two hormones were given singly, LH was the more effective but when both hormones were given together, they acted in synergy.

Since hypophysectomy is an operation that disrupts the normal functioning of an animal, these effects may have simply reflected this disruption. However, there is other evidence supporting the hypothesis that at least FSH affects Sertoli cell numbers in the developing ram. First, supplementation of normal ram lambs with FSH increased Sertoli cell numbers after only $5 \mathrm{~d}$ of treatment $[8,9]$. Second, hemicastration of ram lambs early in their life provoked an immediate increase in blood FSH levels followed soon after by an increase in Sertoli cell divisions $[42,43]$ and, later, by an increase in spermatid production [21].

Evidence for the role of FSH is also available in other species (see review by Sharpe [35]). In the immature rat, hypophysectomy followed by supplementation with FSH [13] or suppression of FSH either by immunization [34] or with testosterone propionate [2, 3 ] or in vitro organ culture of the immature rat testis [6] indicated that the premeiotic steps of spermatogenesis are sensitive to FSH deprivation. The sensitivity of these steps to FSH has also been shown in mature rats treated with a GnRH antagonist [37] or immunized against GnRH [28] as well as in juvenile and adult monkeys [5, 27, 41] and hpg mice [36]. Finally, hemicastration of boars at a young age has also been shown to increase Sertoli cell numbers in the remaining testis $[26,33]$ accompanied by a transient increase in blood FSH levels [25].

However, most of this evidence is indirect. Direct evidence for a role of FSH in testicular function is seen in studies on the adult ram [23, 24], wherein passive immu- 
nization against ovine $\beta$-FSH severely disrupted spermatogenesis at the level of the later spermatogonial divisions without interfering with Sertoli cell numbers. However, similar direct evidence is not available for young rams where the Sertoli cell population is still establishing and spermatogenesis has not yet reached adult levels. Therefore, the experiments reported here were designed to test the hypothesis that long-term immunosuppression of FSH in ram lambs would interfere with the establishment of the normal population of Sertoli cells and also disrupt the onset of spermatogenesis.

\section{MATERIALS AND METHODS}

\subsection{Animals and experimental protocol}

The three groups of ram lambs used in the study were all of the Ile-de-France breed born at the Inra Reproductive Physiology Research Station. Lambs in any one group were all born within a 5-d period and killed at the end of treatment.

The first group of five lambs (initial controls) was born in autumn and killed at birth. The second group of rams (experiment 1) was born in autumn and immunized with one of two batches of antiserum, Anti-FSH $1(n=7)$ or Anti-FSH $2(n=6)$ from birth until 100 days of age. Control animals $(n=6)$ were treated with a similar volume of normal horse $\gamma$-globulins. Animals were housed in a light-proof room with a photoperiod similar to that of spring. The third group of rams (experiment 2) was born in spring and treated from birth with antiserum (Anti-FSH 3) or normal horse $\gamma$-globulins (controls). Some of these animals were treated for $100 \mathrm{~d}$ (six controls, five treated animals), while the rest were treated for $160 \mathrm{~d}$ (seven controls, six treated animals). These animals were also housed in a lightproof room with a photoperiod similar to that of the animals in experiment 1 .

The rationale behind the treatments was as follows. The initial controls were used to measure testicular parameters at birth and serve as a baseline, particularly for Sertoli cells. Experiment 1 lasted until the commencement of the phase of rapid testicular growth, as determined by weekly measurements of testicular volume by compara- tive palpation using an orchidometer [30]. Some of the animals of experiment 2 were also treated until this age, while the rest were allowed to proceed another 2 months to allow spermatogenesis to establish [12]. In order that the results of experiments 1 and 2 should be comparable, the animals were housed and subjected to artificial photoperiodic regimes similar to a natural springtime photoperiod. Animals were weighed monthly and their weekly weights, estimated from their growth curves, were used to calculate the volume of the testes relative to liveweight.

\subsection{Preparation of antisera}

Anti-FSH antisera were prepared in two mares by intradermic immunization at approximately monthly intervals with the $\beta$ sub-unit of ovine FSH (provided by M.R. Sairam). Two weeks after immunization, a large volume of blood (at least $1 \mathrm{~L}$ ) was taken from each mare and the serum collected. Control serum was obtained from the blood of non-immunized horses. The $\gamma$-globulin fractions of the antisera and the normal serum were prepared by precipitation with ammonium sulphate followed by dialysis against physiological saline; these fractions were then prepared for injection by sterile filtration.

Three batches of antiserum were used in the two experiments. Two of these batches (AntiFSH 1,3) came from one mare but on different dates separated by at least 4 weeks; the other batch (Anti-FSH 2) came from a second mare.

The titres of the antisera were measured by determining the capacity of serial dilutions to bind ${ }^{125}$ I-labelled $\mathrm{FSH}$, while their cross-reactions with LH were defined as the ratio of FSH to LH which gave $50 \%$ displacement of labelled FSH. The titres of the three antisera were $1 / 64000,1 / 8000$ and 1/32 000 for Anti-FSH 1, 2 and 3 , respectively, while their respective crossreactions with $\mathrm{LH}$ were $0.3,0$ and $0.3 \%$. The ability of the three antisera to neutralize FSH in vivo was assessed using the bioassay for FSH described by Steelman and Pohley [38]. A dose of $0.1 \mathrm{~mL}$ of each of the antisera negated the response in terms of rat ovarian weight augmentation when $20 \mu \mathrm{g}$ of FSH (equivalent to $10 \times \mathrm{NIH} \mathrm{S1)}$ was injected in conjunction with $20 \mathrm{IU}$ hCG.

\subsection{Immunization}

Ram lambs were injected subcutaneously twice weekly with a dose of antiserum that 
increased with age. This dose started at $1.0 \mathrm{~mL}$ at birth and increased to $5.0 \mathrm{~mL}$ at a liveweight of approximately $35 \mathrm{~kg}$; control rams received an equivalent dose of normal horse $\gamma$-globulins. At weekly intervals a blood sample was taken from the animals of experiment 1 and the plasma stored at $-20^{\circ} \mathrm{C}$. In experiment 2 , lambs underwent serial bleeding at ages of 59 and $99 \mathrm{~d}$ of age and, in the animals treated for $160 \mathrm{~d}$, at 159 d of age. At these bleeds, a blood sample was taken every $20 \mathrm{~min}$ over an 8-h period and the plasma stored at $-20^{\circ} \mathrm{C}$. Because of the apparent lack of efficacy of antiserum from the second mare in experiment 1 , only antiserum from the first mare was used in experiment 2.

\subsection{Morphometry and germinal cell production}

All animals were weighed immediately prior to death. The procedures relating to testicular morphology and germinal cell production have been described in detail by Kilgour et al. [23]. Briefly, immediately after death, the testes were removed and weighed and a small portion of each testis was processed for light microscopy.

The relative volume of the seminiferous tubular tissue and the diameter and length of the seminiferous tubules were measured. Since treatment with anti-FSH antisera has been previously shown to affect the nuclear size of Sertoli cells but not germinal cells [23], the perimeters of the nuclei of ten randomly selected Sertoli cells were measured for each ram using a semi-automatic image analyser (Mini-MOP, Carl Zeiss). The perimeter measurements were then transformed to diameters, assuming the nuclei to be spherical. These diameters were then used in the calculation of the number of Sertoli cells per testis by correcting the raw counts according to Abercrombie [1].

In the lambs of experiment 2 treated for $160 \mathrm{~d}$, spermatogenesis had begun but had not reached adult levels as adjudged by the number of tubules with incomplete spermatogenesis. In order to account for this in the measurement of the germinal cellular component of the testis, 200 tubules of round cross-section were selected at random and their stage classified according to Ortavant's [31] classification of the stages of the cycle of the seminiferous epithelium.

The testicular content of Sertoli cells and of type $A_{0}$ spermatogonia was measured as were the daily productions of $A_{1}$ and $B_{2}$ spermatogonia, of leptotene and pachytene spermatocytes and of round spermatids [4]. These measurements of daily production were then corrected for the proportion of tubules with identifiable stages. In the case of the $A_{1}$ and $B_{2}$ spermatogonia, this was done by calculating for each ram the proportion of tubules at stage 8 and dividing this by the expected proportion of tubules at this stage in the mature ram. The calculated daily production of $\mathrm{A}_{1}$ and $\mathrm{B}_{2}$ spermatogonia was then multiplied by this proportion. Similar corrections were made for the daily production of leptotene (stage 2) and pachytene (stage 3) spermatocytes and of round spermatids (stage 6 ).

Finally, the daily production of the various germinal cells was expressed on a per-100-Sertoli-cell basis in order to assess whether any effects of immunization on daily production of germinal cells was simply a reflection of changes in Sertoli cell numbers.

\subsection{Hormonal measurements}

The concentration of LH was measured in plasma using the double-antibody radioimmunoassay developed by M.R. Blanc and J.C. Poirier (unpublished) which was described in detail by Kilgour et al. [23]. Testosterone concentration was measured as described by Garnier et al. [19]. FSH was not measured owing to the presence of anti-FSH antibodies in the plasma of the treated animals.

All samples from the same animal were assayed together. The concentrations of $\mathrm{LH}$ and testosterone were estimated using the four-parameter procedure described by Dudley et al. [18]. In the animals of experiment 2 , a pulse of LH was deemed to have occurred where there was a statistically significant rise (greater than three standard deviations of the lower concentration) in LH concentration between one sample and the next or between one sample and the next two followed by a consistent decrease over at least three consecutive samples. A peak of testosterone was deemed to have occurred where a statistically significant (five standard deviations) increase occurred within three or four samples. Four parameters relating to the secretion of $\mathrm{LH}$ and testosterone were then calculated for each animal. These were overall mean concentration. mean basal level, mean pulse height and pulse frequency.

\subsection{Statistical analyses}

All data were analysed by least-square analysis of variance using raw data except in the case of number of pulses where data were transformed by $\sqrt{(x+0.5)}$. 


\section{RESULTS}

\subsection{Initial controls}

The data pertaining to the ram lambs killed shortly after birth are presented in table $I$. As usually observed in newborn male lambs, the seminiferous epithelium was populated mainly by supporting cells, the precursors of the Sertoli cells, and occasional undifferentiated germinal cells or stem spermatogonia. There was no evidence of the evolution of the germinal cells into more highly differentiated cells such as spermatocytes or spermatids.

\subsection{Experiment 1}

Immunization with Anti-FSH 1 retarded testicular development resulting in a $36 \%$ lower $(P<0.05)$ seminiferous tubular length and a $29 \%$ lower $(P<0.05)$ number of Sertoli cells per testis relative to control animals (table II). None of these effects was due to an effect on general body growth which was unaffected by treatment as shown by the lack of effect on live weight (table II). There were no other significant effects of Anti-FSH 1 on any of the other testicular parameters measured, although testicular weight, seminiferous tubular diameter and Sertoli cellular nuclear diameter were all lower in treated animals (table II). Immunization with Anti-FSH 2 had no significant effect on any of the testicular parameters measured, and the apparent increase in all of these was due to three of the animals in this group entering the phase of rapid testicular growth well ahead of the controls.

\subsection{Experiment 2}

Immunization with Anti-FSH 3 also significantly retarded testicular growth, wherein a marked slowing of testicular development occurred from around the time of the rapid phase of testicular development around 60 to $70 \mathrm{~d}$ of age seen in the controls (figure 1). This was also reflected in the following events within the testis.

\subsubsection{0 days}

In animals treated with Anti-FSH 3, testicular weight was only $37 \%$ of that of the controls $(P<0.05)$, while seminiferous tubular length was $62 \%$ of that of the control animals $(P<0.05$; table III $)$. Seminiferous tubular diameter, Sertoli cell nuclear size and the testicular number of Sertoli cells were also lower than in the controls, but none of these differences were statistically significant. Nor were any of these differences a result of an effect on liveweight which did not differ significantly between treated and control animals (table III).

At both 59 and $99 \mathrm{~d}$ of age, almost all rams had at least one pulse of testosterone during the sampling period, the number of which varied from 0 to 3 . There were no significant differences between the control and treated rams in the number of $\mathrm{LH}$ pulses

Table I. Mean ( \pm s.e.m.) testicular weight, diameter and length of the seminiferous tubules, and mean nuclear diameter and total numbers per testis of Sertoli cells of the five lambs killed at birth.

\begin{tabular}{ccccc}
\hline $\begin{array}{l}\text { Testicular } \\
\text { weight }(\mathrm{g})^{1}\end{array}$ & \multicolumn{2}{c}{ Seminiferous tubular } & $\begin{array}{c}\text { Nuclear } \\
\text { diameter of } \\
\text { Sertoli cells }(\mu)\end{array}$ & $\begin{array}{c}\text { No. of Sertoli } \\
\text { cells per testis } \\
\left(\times 10^{8}\right)\end{array}$ \\
\hline 0.68 & 37.4 & 138.0 & Length $(\mathrm{m})$ & $\begin{array}{c}5.44 \\
\pm 0.07\end{array}$ \\
\hline 0.08 & \pm 0.9 & \pm 15.6 & \pm 0.3 \\
\hline
\end{tabular}

\footnotetext{
' Mean of left and right.
} 


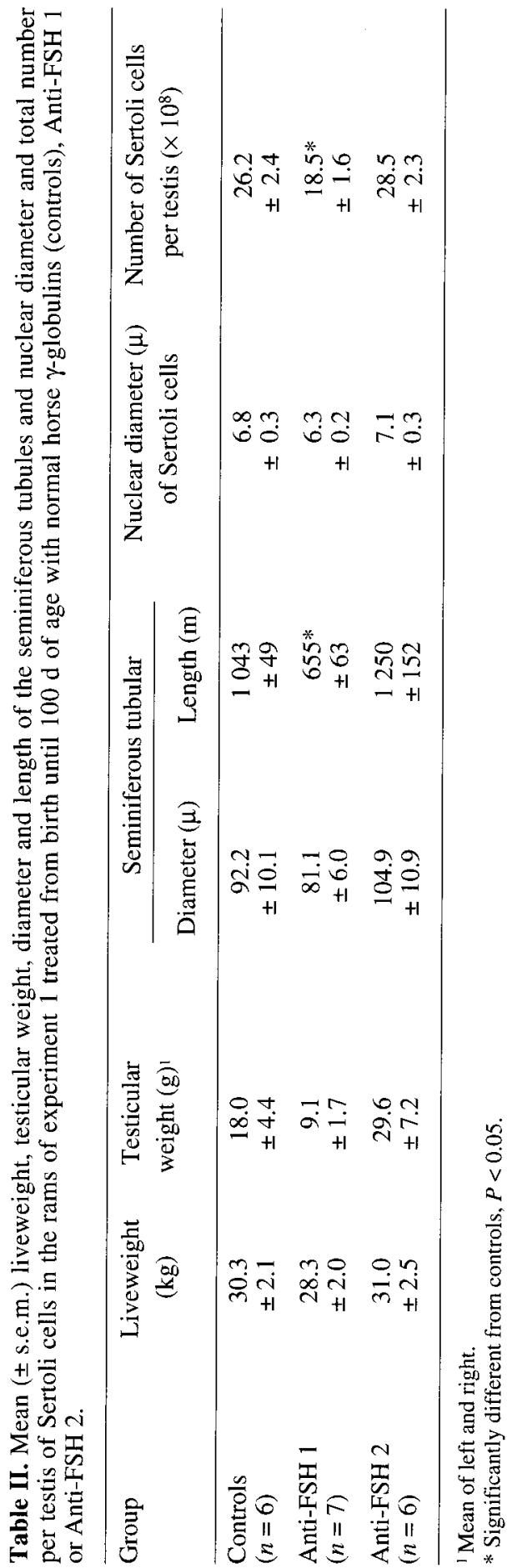

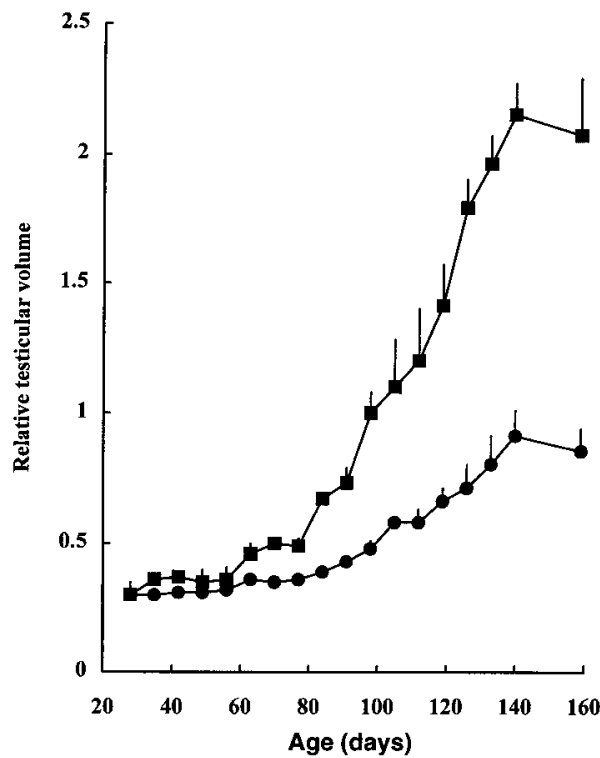

Figure 1. Mean ( \pm s.e.m) relative testicular volume ( $\mathrm{mL}$ testicular tissue $/ \mathrm{kg}$ liveweight) of the ram lambs of experiment 2 passively immunized for $160 \mathrm{~d}$ with normal horse $\gamma$-globulins (squares) or with Anti-FSH 3 (circles). Where no error bar appears, error is smaller than the symbol.

at 59 and 99 d. However, at 59 d, pulse height was significantly higher in the treated rams, while at $99 \mathrm{~d}$ overall mean, pulse height and base level were all significantly higher in treated rams (figure 2). There were no significant differences between the two groups of rams in any of the measurements relating to the secretion of testosterone (figure 2).

\subsubsection{0 days}

In the animals treated with Anti-FSH 3, testicular weight was only $42 \%(P<0.001)$ of that of controls, seminiferous tubular length was $48 \%(P<0.001)$, nuclear diameter of the Sertoli cells was $92 \%(P<0.05)$ and the number of Sertoli cells per testis was $57 \%(P<0.01)$ of that of controls (table III). Treatment with antiserum also had significant depressive effects on the 


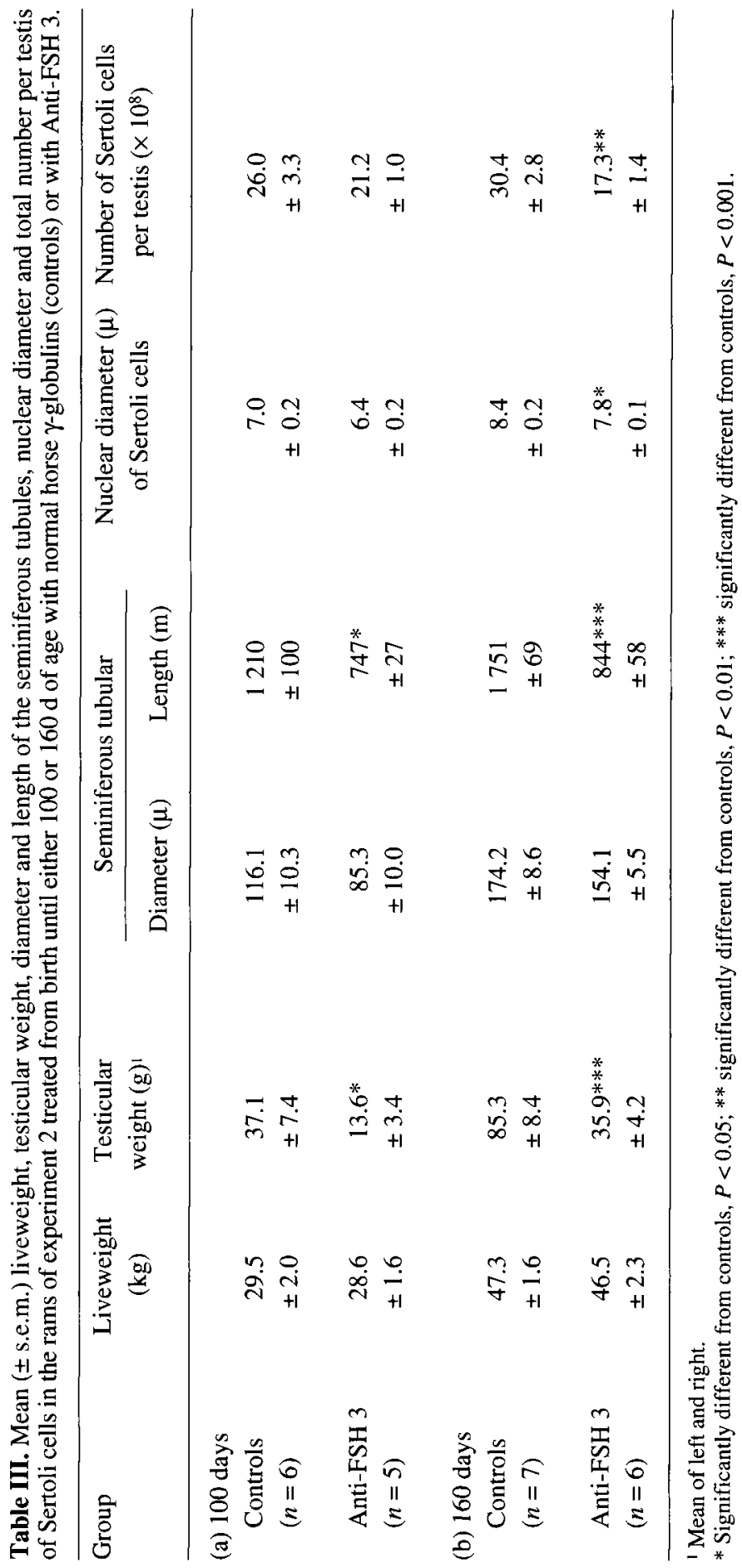




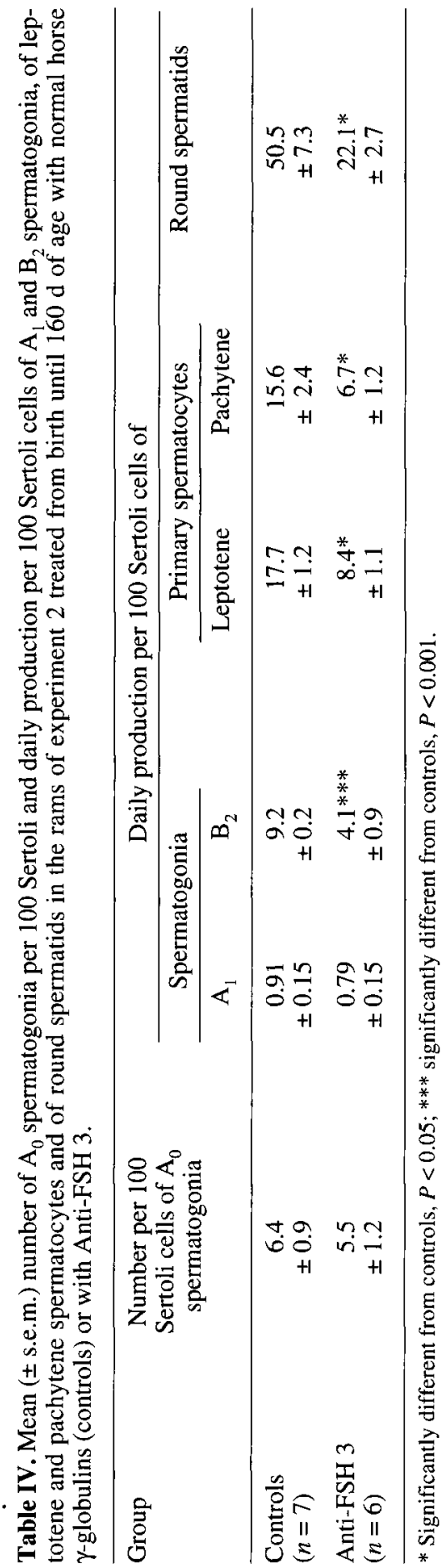

total number of $A_{0}$ spermatogonia per testis and on the total daily production of $A_{1}$ and $\mathrm{B}_{2}$ spermatogonia, of leptotene and pachytene spermatocytes and of round spermatids (data not shown). However, when these data were adjusted for the size of the Sertoli cell population, treatment no longer had any significant effect on the number of $\mathrm{A}_{0}$ spermatogonia per 100 Sertoli cells nor on the daily production per 100 Sertoli cells of $\mathrm{A}_{1}$ spermatogonia (table IV). However, treatment did significantly impair the daily productions of all other types of germinal cells, which were all $43-47 \%$ of their respective controls (table $I V$ ). The ratios of the daily production per 100 Sertoli cells of round spermatids to pachytene spermatocytes (3.2:1 and 3.3:1 in control and treated lambs), of pachytene spermatocytes to leptotene spermatocytes $(0.9: 1$ and $0.8: 1)$ and of leptotene spermatocytes to $\mathrm{B}_{2}$ spermatogonia (1.9:1 and 2.1:1) were similar in the control and treated groups. However, the ratio of $B_{2}$ spermatogonia to $A_{1}$ spermatogonia of treated animals was only $51 \%$ of that of control animals, suggesting that only the spermatogonial divisions between the $A_{1}$ and the $B_{2}$ spermatogonia require $F S H$.

At the serial bleed at $159 \mathrm{~d}$ of age, there were no differences between the treated and control rams in the number of pulses of $\mathrm{LH}$, but pulse height, base level and mean level were all significantly higher in the treated lambs (figure 2). There were no differences between the two groups of animals in any of the parameters relating to testosterone secretion (figure 2).

\section{DISCUSSION}

These two experiments have shown that FSH is necessary for the normal testicular development and for the establishment of the Sertoli cell population in the ram lamb. Furthermore, these experiments have shown that, once spermatogenesis is established, FSH is essential for the differentiation of 
LH
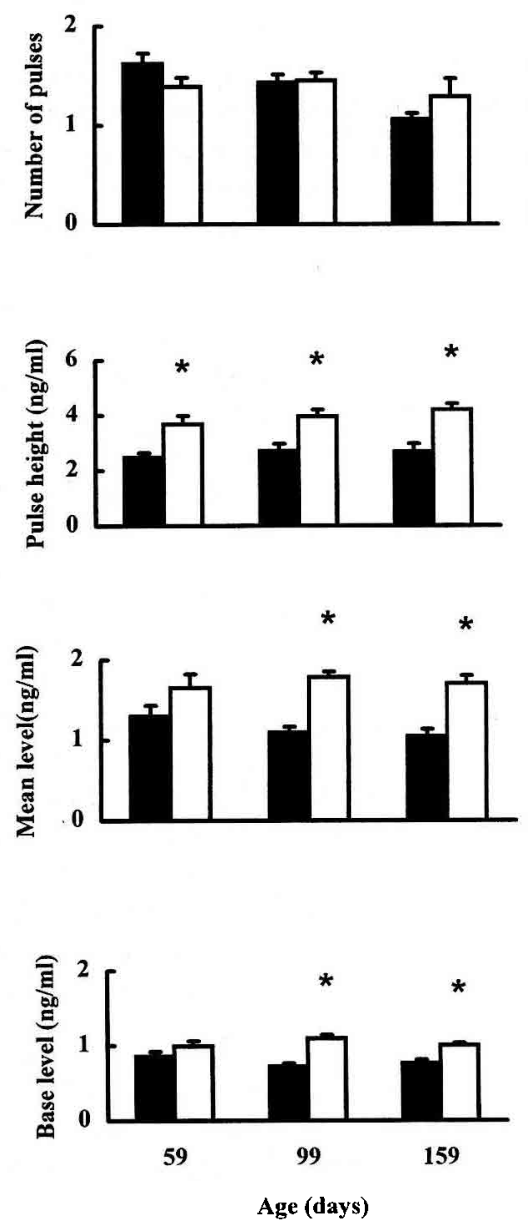

Testosterone
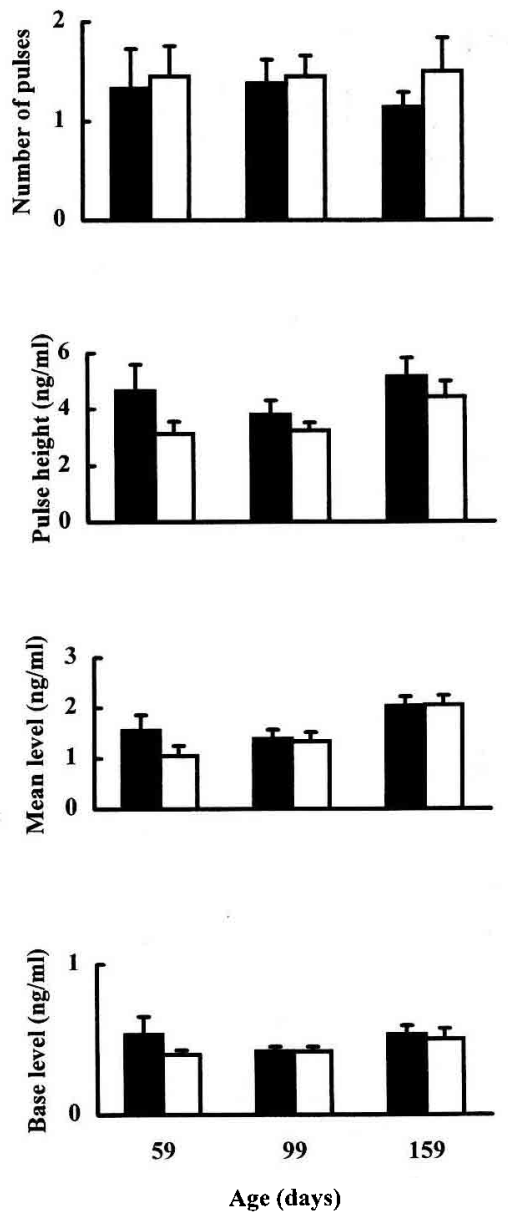

Figure 2. Mean ( \pm s.e.m.) pulse number, pulse height, overall mean and base level of LH (left panel) and testosterone (right panel) in the serial bleeds at 59,99 and $159 \mathrm{~d}$ in the ram lambs of experiment 2 passively immunized for 100 or $160 \mathrm{~d}$ with normal horse $\gamma$-globulins (black columns) or with Anti-FSH 3 (white columns). An asterisk indicates that the treatment differs significantly from control $(P<0.05)$.

$A_{1}$ spermatogonia into $B_{2}$ spermatogonia but that, from a quantitative point of view, earlier or later spermatogenic steps do not require $\mathrm{FSH}$.

The experiments reported here, along with those reported by Kilgour et al. [23, $24]$ give new insight into the role played by FSH in the development of the testis, the establishment of the Sertoli cell population and in the onset and maintenance of spermatogenesis in the ram.

As regards Sertoli cells, the ram lambs of the current study were born with a Sertoli cell population of around $2.5 \times 10^{8}$ cells per testis. This population had increased approximately ten-fold by $100 \mathrm{~d}$ of age (controls, 
experiments 1 and 2), after which time there was little increase up to $160 \mathrm{~d}$ (controls, experiment 2), even to adult ages [23, 24]. Evidence that FSH is necessary for this population to establish is seen in the present study where its withdrawal by passive immunization led to a lowering in Sertoli cell numbers relative to controls ranging from 18 to $43 \%$, but not complete arrest. Similar results were also seen in ram lambs passively immunized from $30 \mathrm{~d}$ of age against FSH with the same antisera [22]. However, in contrast to lambs, the adult rams of Kilgour et al. [23, 24], showed no effect of immunosuppression of FSH on the number of Sertoli cells per testis. Taken together, all of these results indicate that FSH is necessary only for the division of the precursors of the Sertoli cells but not for the quantitative maintenance of an already-established Sertoli cell population.

While FSH withdrawal only resulted in significant decreases in Sertoli cell numbers in two of the three cases reported here (experiment 1 and the 160-d treatment of experiment 2), anti-FSH treatment of the animals treated for $100 \mathrm{~d}$ in experiment 2 did result in an $18 \%$ decrease in the size of the Sertoli cell population. One possible explanation for the lack of significance of this difference is the large coefficient of variation in the group treated with Anti-FSH 2 (greater than $30 \%$ ) compared to coefficients of close to $20 \%$ in the other treated and control groups.

In those animals of the present study immunized up to $160 \mathrm{~d}$ of age, spermatogenesis had become established and, although FSH withdrawal did not completely inhibit spermatogenesis, it did result in large reductions in the production of several types of germinal cells. These reductions were not simply a reflection of the lowered number of Sertoli cells but also an effect on the numbers of germinal cells supported by each Sertoli cell. This evidence indicates that the differentiation of the $A_{0}$ spermatogonia into $A_{1}$ spermatogonia does not require $\mathrm{FSH}$, nor do any of the cellular types from the $\mathrm{B}_{2}$ spermatogonia onward. However, somewhere between the differentiation of the $A_{1}$ into $B_{2}$ exists one, or possibly more, steps that require $\mathrm{FSH}$, a conclusion previously suggested by Courot et al. [14] that is corroborated by similar work in the adult mouse and hamster [17] ram $[15,23,24]$, monkey $[5,27,41]$ and rat $[6,28,37]$.

From the experiment reported here, these above effects appear to be due to an effect on FSH alone, and not to any effect on the secretion of LH or testosterone. Evidence for this is seen in the lack of effect on the plasma levels of the two hormones which, if affected at all, were increased in the case of some LH parameters.

These results are consistent with other experiments on young animals which have shown an influence of FSH on the Sertoli cell population under a range of experimental conditions. These have included hypophysectomy or administration of antiserum to FSH to foetal rats [32], administration of FSH to neonatal rats $[2,40]$ and hpg mice [36], treatment of normal ram lambs with FSH for as little as $5 \mathrm{~d}$ [8, 9], hypophysectomy and hormonal replacement of young rams [10, 12] and rats [11, 29], suppression of FSH in immature and adult rats followed by treatment with hFSH ([2] see review by Sharpe [35]).

The results are also consistent with those concerning germinal cell production in the monkey $[5,27,41]$ and young rat where the $A_{1}$ spermatogonia appear not to be sensitive to hormones, while the more mature spermatogonia and, as a consequence, spermatocytes are under the influence of FSH $[2,6,7,11,20,28,34,37]$. However, there is no evidence from the experiments reported here of a quantitative effect of FSH on spermiogenesis in the young ram as has been postulated in the rat $[3,28,39]$.

In conclusion, FSH appears to be essential for the normal development of the testis and the establishment of the normal popu- 
lation of Sertoli cells in at least two mammalian species because it is necessary for normal Sertoli cellular division. Once spermatogenesis has established, FSH also appears to be necessary for the late spermatogonial divisions, possibly by decreasing the number of spermatogonia that degenerate [16]. It is likely that this effect on the germinal cells operates through the Sertoli cells since immunosuppression of FSH decreased the size of their nuclei. However, the data reported here cannot be used to conclude that FSH is the sole hormone responsible for normal testicular development, since testicular growth and spermatogenesis were not completely arrested. While this may have been due to incomplete suppression of FSH, the evidence of the involvement of other hormones such as $\mathrm{LH}$ and $\mathrm{GH}$ $[8,12]$ cannot be discounted.

\section{ACKNOWLEDGEMENTS}

We thank B.M. Bindon and D.R. Lindsay for their constructive comments on the manuscript; M.R. Sairam for the $\beta$ sub-unit of FSH; M.M. de Reviers for bioassay of the antisera and M.T. Hochereau-de Reviers for assistance with histology of the $A_{0}$ spermatogonia. R.J. Kilgour was supported by a Post Graduate Scholarship from the Australian Meat and Livestock Research and Development Corporation and by the Department of Agriculture, New South Wales. The loan of the semi-automatic image analyser from Carl Zeiss, Sydney is gratefully acknowledged. We also acknowledge the technical assistance of C. Cornu, G. Durand and the sheep management team and of G. Duchamp and the horse management team.

\section{REFERENCES}

[1] Abercrombie M., Estimation of nuclear population from microtome sections, Anat. Rec. 94 (1946) 239-247.

[2] Almiron I., Chemes H., Spermatogenic onset. II. FSH modulates mitotic activity of germ and Sertoli cells in immature rats, Int. J. Androl. 11 (1988) 235-246.

[3] Almiron I., Domene H., Chemes H.E., The hormonal regulation of premeiotic steps of spermatogenesis in the newborn rat, J. Androl. 5 (1984) 235-242.
[4] Amann R.P., Sperm production rates, in: Johnson A.D., Gomes W.R., Vandemark N.L. (Eds.), The Testis, Vol. 1, Academic Press, New York, 1970, pp. 433-482.

[5] Arslan M., Weinbauer G.F., Schlatt S., Shahab M., Nieschlag E., FSH and testosterone, alone or in combination, initiate testicular growth and increase the number of spermatogonia and Sertoli cells in a juvenile non-human primate (Macaca mulatta), J. Endocr. 136 (1993) 235-243.

[6] Boitani C., Politi M.G., Menna T., Spermatogonial cell proliferation in organ culture of immature rat testis, Biol. Reprod. 48 (1993) 761-767.

[7] Chemes H.E., Dym M., Raj H.G.M., The role of gonadotropins and testosterone on initiation of spermatogenesis in the immature rat, Biol. Reprod. 21 (1979) 241-249.

[8] Courot M., Développement du testicule chez l'agneau. Établissement de la spermatogenèse, Ann. Biol. Anim. Bioch. Biophys. 2 (1962) 25-42.

[9] Courot M., Action des hormones gonadotropes sur le testicule de l'agneau, Ann. Biol. Anim. Bioch. Biophys. 5 (1965) 145-149.

[10] Courot M., Endocrine control of the supporting and germ cells of the impuberal testis, J. Reprod. Fertil. Suppl. 2 (1967) 89-101.

[11] Courot M., Effect of gonadotropins on the seminiferous tubules of the immature testis, Adv. Exp. Med. Biol. 10 (1970) 355-367.

[12] Courot M., Établissement de la spermatogenèse chez l'agneau (Ovis aries). Étude expérimentale de son contrôle gonodotrope thèse, importance de la lignée sertolienne, University of Paris VI, CNRS: A.O.6317, 1971, 200 p.

[13] Courot M., Ortavant R., de Reviers M.M., Variations du contrôle gonadotrope du testicule selon l'âge des animaux, Exp. Anim. 4 (1971) 201-2 I1.

[14] Courot M., Hochereau-de Reviers M.-T., MonetKuntz C., Locatelli A., Blanc M.R., Dacheux J.L., Endocrinology of spermatogenesis in the hypophysectomized ram, J. Reprod. Fertil. Suppl. 26 (1979) 165-173.

[15] Courot M., Hochereau-de Reviers M.-T., Pisselet C., Kilgour R.J., Dubois M.P., Sairam M.R., Effect of passive immunization against ovine $\beta$-FSH on spermatogenesis in the ram, in: Courot M. (Ed.), The Male in Farm Animal Reproduction, Martinus Nijhoff Publishers, Boston, 1984, pp. 75-79.

[16] Desclin J., Ortavant R., Influence des hormones gonadotropes sur la durée des processus spermatogénétiques chez le rat, Ann. Biol. Anim. Bioch. Biophys. 3 (1963) 329-342.

[17] Dissel-Emiliani F.M.F., van Grootenhuis A.J., de Rooij D.G., de Jong F.H., Inhibin reduces spermatogonial numbers in testes of adult mice and Chinese hamsters, Endocrinology 125 (1989) 1898-1903. 
[18] Dudley R.A., Edwards P., Ekins R.P., Finney D.J., McKenzie I.G.M., Raab G.M., Rodbard D., Rodgers R.P.C., Guidelines for immunoassay data processing, Clin. Chem. 31 (1985) 1264-1271.

[19] Garnier D.H., Cotta Y., Terqui M., Androgen radioimmunoassay in the ram results of direct plasma testosterone and dihydroepiandrosterone measurement and physiological evaluation, Ann. Biol. Anim. Bioch. Biophys. 18 (1978) 265-281.

[20] Graf K.M., Dias J.A., Griswold M.D., Decreased spermatogenesis as a result of an induced autoimmune reaction directed against the gonadotropin receptors in male rats, J. Androl. 18 (1997) 174-185.

[21] Hochereau-de Reviers M.-T., Land R.B., Perreau C., Thompson R., Effect of season of birth and of hemicastration on the histology of the testis of 6-month-old lambs, J. Reprod. Fertil. 70 (1984) 157-163.

[22] Kilgour R.J., Pisselet C., Dubois M.P., Courot M., Sairam M.R., The role of FSH in the establishment of spermatogenesis in the lamb, 10th Int. Cong. Anim. Reprod. Artif. Insem., 10-14 June 1984, Urbana-Champaign, Illinois Brief Communications, Paper no. 42, 1984

[23] Kilgour R.J., Courot M., Pisselet C., Dubois M.P., Sairam M.R., Inhibition of FSH affects spermatogenesis in the mature ram, Anim. Reprod. Sci. 32 (1993) 213-225.

[24] Kilgour R.J., Courot M., Pisselet C., Dubois M.P., Sairam M.P., Inhibition of FSH but not LH affects spermatogenesis in the mature ram, Anim. Reprod. Sci. 34 (1994) 253-264.

[25] Kosco M.S., Bolt D.J., Wheaton J.E., Loseth K.J., Crabo B.G., Endocrine responses in relation to compensatory testicular growth after neonatal hemicastration in the neonatal boar, Biol. Reprod. 36 (1987) 1177-1185.

[26] Kosco M.S., Loseth K.J., Crabo B.G., Development of the seminiferous tubules after neonatal hemicastration in the boar, J. Reprod. Fert. 87 (1989) 1-11.

[27] Marshall G.R., Zorub D.S., Plant T.M., Follicle-stimulating hormone amplifies the population of differentiated spermatogonia in the hypophysectomized testosterone-replaced adult Rhesus monkey (Macaca mulatta), Endocrinology 136 (1995) 3504-3511.

[28] McLachlan R.I., Wreford N.G., de Kretser D.M., Robertson D.M., The effects of recombinant follicle-stimulating hormone on the restoration of spermatogenesis in the gonadotropin-releasing hormone-immunized adult rat, Endocrinology 136 (1995) 4035-4043.

[29] Murphy H.D., Sertoli cell stimulation following intratesticular injections of FSH in the hypophysectomized rat, Proc. Soc. Exp. Biol. Med. 118 (1965) 1202-1205.

[30] Oldham C.M., Adams N.R., Gherardi P.B., Lindsay D.R., Mackintosh J.B., The influence of level of feed intake on sperm-producing capacity of testicular tissue in the ram, Aust. J. Agric. Res. 29 (1978) 173-179.

[31] Ortavant R., Déroulement et durée du cycle spermatogénétique chez le bélier. Première partie. Définition et étude histologique du cycle spermatogénétique, Ann. Zootech. 8 (1959) 183-244.

[32] Orth J.M., The role of follicle-stimulating hormone in controlling Sertoli cell proliferation in testes of fetal rats, Endocrinology 115 (1984) $1248-1255$.

[33] Putra D.K.H., Blackshaw A.W., Quantitative studies of compensatory hypertrophy following unilateral castration in the boar, Aust. J. Biol. Sci. 38 (1985) 429-434.

[34] Raj H.G.M., Dym M., The effects of selective withdrawal of FSH or LH on spermatogenesis in the mature rat, Biol. Reprod. 14 (1976) 489-494.

[35] Sharpe R.M., Regulation of spermatogenesis, in: Knobil E., Neill J.D. (Eds.), The Physiology of Reproduction, 2nd ed., vol. 1, Raven Press Publishers, New York, 1994, pp. 1363-1434.

[36] Singh J., Handelsman D.J., Neonatal administration of FSH increases Sertoli cell numbers and spermatogenesis in gonadotropin-deficient (hpg) mice, J. Endocr. 151 (1996) 37-48.

[37] Sinha Hikim A.P., Swerdloff R.S., Temporal and stage-specific effects of recombinant human follicle-stimulating hormone on the maintenance of spermatogenesis in gonadotropin-releasing hormone antagonist-treated rat, Endocrinology 136 (1995) 253-261.

[38] Steelman S.L., Pohley F.P., Assay of the follicle stimulating hormone based on the augmentation with human chorionic gonadotropin, Endocrinology 53 (1953) 604-616.

[39] Steinberger E., Duckett G.E., Hormonal control of spermatogenesis, J. Reprod. Fertil. Suppl. 2 (1967) 75-87.

[40] Ultee-van Gessel A.M., Timmerman M.A., de Jongh F.H., Effects of treatment of neonatal rats with highly purified FSH alone and in combination with $L H$ on testicular function and endogenous hormone levels at various ages, $\mathrm{J}$. Endocr. 116 (1988) 413-420.

[41] Van Alphen M.M.A., van de Kant H.J.G., de Rooij D.G., Follicle-stimulating hormone stimulates spermatogenesis in the adult monkey, Endocrinology 123 (1988) 1449-1455.

[42] Waites G.M.H., Wenstrom J.C., Crabo B.G., Hamilton D.W., Rapid compensatory hypertrophy of the ram testis after neonatal hemiorchidectomy: endocrine and light microscopical morphometric analyses, Endocrinology 112 (1983) 2159-2167.

[43] Walton J.S., Evins J.D., Waites G.M.H., Feedback control of follicle-stimulating hormone in pre- and postpubertal rams as revealed by hemicastration, J. Endocr 77 (1978) 75-84. 